\title{
EXTRACTION OF NITRATE FROM POLLUTED WATERS USING ACTIVATED BIOADSORBENTS DERIVED FROM LEAVES, BARKS OR STEMS OF PHYLLANTHUS NERURI, MORINGA TINCTORIA AND AZADIRACTA INDICA
}

\author{
M. Suneetha ${ }^{1}$ and K. Ravindhranath ${ }^{2} *$ \\ Department of Engg. Chemistry and Post Graduate Chemistry, Bapatla Engineering College, BAPATLA-422101, Guntur \\ Dt., Andhra Pradesh
}

\begin{abstract}
Bio-adsorbents derived from leaves, stems or barks of Phyllanthus Neruri, Moringa Tinctoria and Azadiracta Indica have been probed for their sorption abilities towards Nitrate ions using simulated polluted waters. At low $\mathrm{pH}$ values, these sorbents show affinity towards Nitrates. The physicochemical parameters such as $\mathrm{pH}$, time of equilibration and sorbent concentrations are optimized for the maximum removal of Nitrates. Methodologies have been developed to extract good quantities of Nitrates. Percentage of extraction with stems powders are found to be more than the respective leaves powders. Optimum time of equilibration and sorbent dosage needed are found to be less for stem powders than the corresponding leaves powders and further, more then $80.0 \%$ percentage of extractions are found with stem powders even at $1.0 \mathrm{hr}$ equilibration time. Common cations present in waters, have synergistic effect on the percentage of extraction while other common anions, except sulphate, have marginal effect. The procedures developed are found to be successful with real samples of industrial effluents and polluted lakes.
\end{abstract}

Key Words: Nitrates; pollution control; bio-adsorbents; Phyllanthus Neruri; Moringa Tinctoria; Azadiracta Indica.

\section{INTRODUCTION}

Nitrate is one of the potential pollutants present in water bodies when nitrogenous compounds are completely oxidized by aerobic degradation [1-5]. More concentrations of nitrate in drinking waters cause Methemoglobin in infants. In the intestinal tract of infants, bacteria converts the nitrate ion to nitrite ion, which reacts with a wide range of secondary and tertiary amines and amides to produce p-nitroso compounds, most of these compounds are potent Carcinogens. In stomach where acidic conditions prevail, the reactions occur quite rapidly affecting the ability of blood cells to absorb oxygen. This causes slow suffocation of the infants, which may lead to death. Because of the oxygen deprivation, the infant will often take on a blue or purple tinge in the lips and extremities and hence the name, blue baby syndrome [6-9].

There are many sources identified as potential source of nitrogen contamination. They are both natural and anthropogenic origin [1-4]. Anthropogenic sources, most often, cause the amount of nitrogen compounds in waters to rise to dangerous levels. Improper disposal of waste materials, human and animal sewages, industrial wastes related to food processing and munitions, accidental spilling of nitrogenous materials and leakage of Septic tanks are some of the examples [5]. Ground water contamination is usually related to the density of septic systems. In densely populated areas, septic systems turn to be major local source of nitrogen compounds to the groundwater. Another potential source of nitrate contamination is the run offs from the agricultural fields using excessive fertilizers in the nearby areas and from the leaches of manure stores.

Due to harmful biological effects [6-9], United States Environmental Protection Agency has fixed health advisory level of nitrate at $45 \mathrm{ppm} \quad[4,10]$.

Many efforts have been envisaged by the various groups of researchers [6,11-20] throughout the Globe in reducing nitrogen-nitrate concentration in polluted waters by evoking physicochemical phenomenon such as Ion Exchange [21-23]. Biochemical de-nitrification [24-26], Reverse Osmosis [22, 27], Electodialysis [28] and Catalytic denitrification [29].These methods have one or other disadvantages and more over, these methods involves complicated procedures and expenditure. A universally acceptable procedure is still eluding the researchers. 
Increasing research interest is being envisaged during the recent past, in evolving procedures using bioprocess of microorganisms and bio-adsorbents derived from flora and fauna materials in controlling the polluting ions. These bioprocesses along with other chemical processes are proving to be potential alternative to the existing methods of detoxification and for the recovery of toxic and valuable ions from industrial discharges/ polluted waters [30-33]. These biological approaches have shown interesting results, which have stimulated continuous and expanding research in this field [34-51]. Our research labs are also making efforts in this aspect of pollution control methods and some successful procedures developed have been reported to the Literature [52-56].

In the present work, sorption abilities of thermally activated bio-adsorbents derived from leaves and barks/ stems of some plants have been explored with an object of controlling the concentration of nitrates in the polluted waters by optimizing various physicochemical parameters such as $\mathrm{pH}$, time of equilibration and sorbet concentrations.

\section{MATERIALS AND METHODS}

A: Chemicals: All chemicals used were of analytical grade. Stock solution of Nitrate of concentration of 500 ppm was prepared and it was suitably diluted as per the need.

B: Adsorbents: Diverse adsorbents of flora origin were used in this work. But leaves or barks or stems of Phyllanthus Neruri, Moringa Tinctoria and Azadiracta Indica have been found to have affinity towards nitrates.

Leaves or stems/barks of Phyllanthus Neruri, Moringa Tinctoria and Azadiracta Indica were freshly cut or scraped from the plants, washed with tap water and then with distilled water. The leaves were then sun dried. The dried leaves were powdered to a fine mesh of size: $<75$ microns and then, they were activated at $105^{\circ} \mathrm{C}$. Thus, obtained powders were used for study.

C: Adsorption experiment: Batch system of extraction procedure was adopted [36, 37, and 57]. Carefully weighted quantities of adsorbents were taken into previously washed one lit $/ 500 \mathrm{ml}$ stopper bottles containing $500 \mathrm{ml} / 250 \mathrm{ml}$ of potassium nitrate solution of predetermined concentrations. The various initial $\mathrm{pH}$ values of the suspensions were adjusted with dil. $\mathrm{HCl}$ or dil. $\mathrm{NaOH}$ solution using $\mathrm{pH}$ meter. The samples were shaken vigorously in mechanical shakers and were allowed to be in equilibrium for the desired time. After the equilibration period, an aliquot of the sample was taken for Nitrate determination. Nitrate was determined spectrophotometrically $[4,58]$. $\mathrm{NO}_{3}{ }^{-}$was reduced quantitatively to $\mathrm{NO}_{2}{ }^{-}$using Cd-reduction column. The obtained $\mathrm{NO}_{2}{ }^{-}$was determined by diazotizing with sulfanilamide and coupling with $\mathrm{N}-(1-$ naphthyl)-ethylenediamine dihydrochloride to form highly colored azo dye and O.D. measurements were made at $543 \mathrm{~nm}$ spectrophotometrically. O.D value of un-known solution was referred to standard graph (drawn between O.D and Concentration) prepared with known amounts of Nitrate by adopting method of Least Squares to find concentration of Nitrate in unknown solutions.

\section{D: Effect of interfering ions:}

The interfering ions chosen for study are the common ions present in natural waters, viz., Phosphate, sulphate, fluoride, Chloride, Carbonate, Calcium, Magnesium, Copper and Zinc. The synthetic mixtures of nitrate and of the interfering ions are so made that the concentration of the interfering ion is maintained at five-fold excess to Nitrate ion concentration. $500 \mathrm{ml}$ of these solutions were taken in stopper bottles and then correctly weighted optimum quantities of the promising adsorbents (as decided by the Graph Nos.: A, B and C) were added. Optimum $\mathrm{pH}$ was adjusted with dil. $\mathrm{HCl}$ or dil. $\mathrm{NaOH}$ using $\mathrm{pH}$ meter. The samples were shaken in shaking machines for desired optimum periods and then small portions of the samples were taken out, filtered and analyzed for Nitrates. Percentage of extraction was calculated. The results were presented in the Table: 1

\section{RESULTS AND DISCUSSIONS}

The percentage removal of Nitrate was studied under various parameters with adsorbents derived from leaves or stems/barks of Phyllanthus Neruri, Moringa Tinctoria and Azadiracta Indica. The results are presented in the Graph No: A: 1-3; B: 1\&2; C: $1 \& 2$ and Table No. $1 \& 2$.

The following observations are significant:

1. \% of extractability increases with time for a fixed adsorbent at a fixed $\mathrm{pH}$ and after certain duration, the extractability remains constant, i.e. an equilibrium state has been reached (vide Graph Nos:A:1-3) 
IOSR Journal of Pharmacy

Mar.-Apr. 2012, Vol. 2(2) pp: 282-290
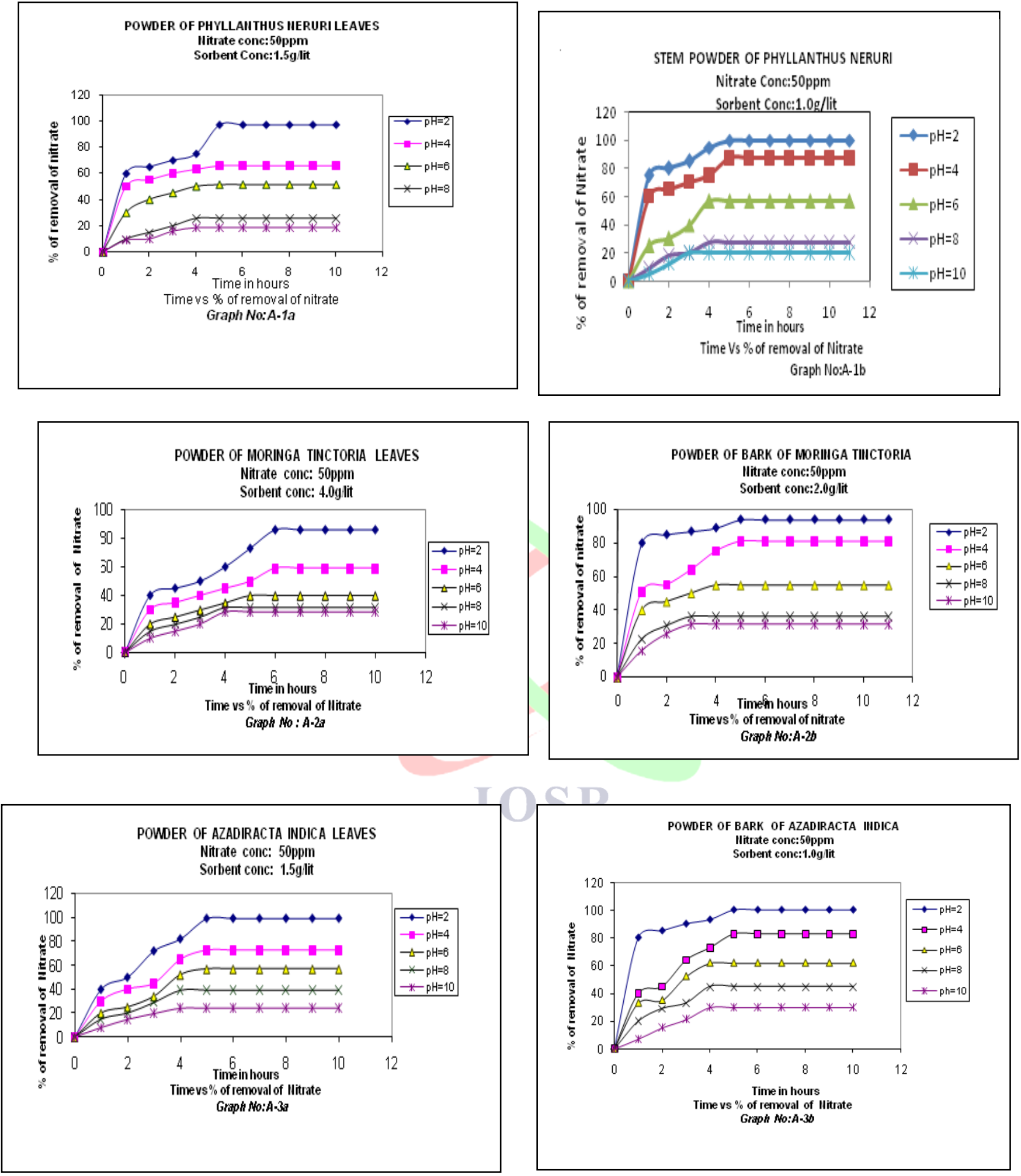

2. pH sensitivity: The $\%$ of extraction is found to be $\mathrm{pH}$ sensitive. The percentage of extractability of Nitrate decreases with the increase of $\mathrm{pH}$ for a fixed adsorbent concentration. (Vide Graph No. : A: 1-3; B: 1\&2). 

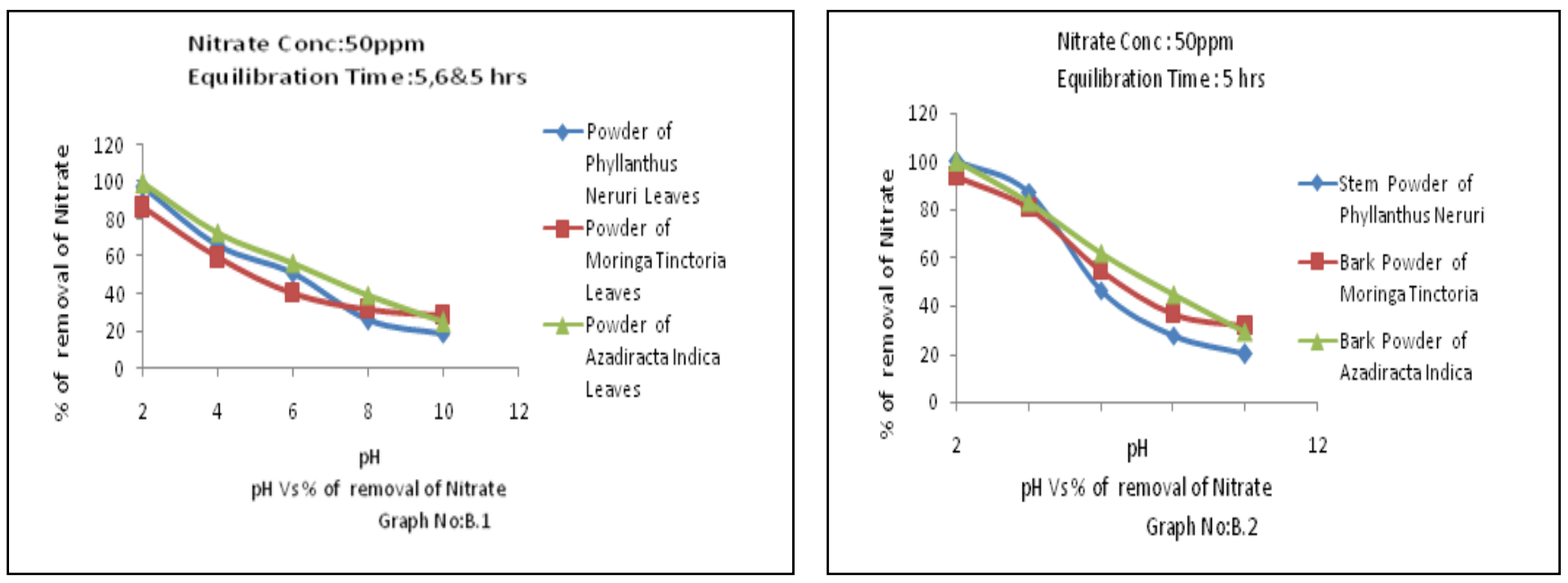

As for example, in the case of leaves powders of Phyllanthus Neruri , the maximum extractability is found to be : $18.6 \%$ at $\mathrm{pH}: 10,25.8 \%$ at $\mathrm{pH}: 8 ; 51.3 \%$ at $\mathrm{pH}: 6 ; 65.8 \%$ at $\mathrm{pH}: 4$ and $97 \%$ at $\mathrm{pH}: 2$. In the case of Moringa Tinctoria, the maximum extractability is found to be : $28.5 \%$ at $\mathrm{pH}: 10,31.8 \%$ at $\mathrm{pH}: 8 ; 40.2 \%$ at $\mathrm{pH}: 6 ; 59.2 \%$ at $\mathrm{pH}: 4$ and $86.0 \%$ at $\mathrm{pH}: 2$. Azadiracta Indica leaves powders extract to an extent of: $24.6 \%$ at $\mathrm{pH}: 10,39.2 \%$ at $\mathrm{pH}: 8 ; 56.7 \%$ at $\mathrm{pH}: 6 ; 72.5 \%$ at $\mathrm{pH}: 4$ and $99.0 \%$ at $\mathrm{pH}: 2$.

With the stem/bark powders, the extractability at pHs: 10, 8,6,4 and 2 is found respectively to be: $19.9 \%, 27.8 \%, 46.5 \%$, $87.2 \%$ and $100 \%$ for Phyllanthus Neruri; $31.8 \%, 36.6 \%, 54.8 \%, 80.9 \%$ and $94 \%$ for Moringa Tinctoria; $29.6 \%, 44.8 \%$, $61.7 \% 82.9 \%, 100.0 \%$ for Azadiracta Indica.

3. The extraction of Nitrate is found to be more in the case of stem/bark powders as sorbents than powders of leaves. Further, the time needed for maximum removal of Nitrate is also found to be less in the case of stem/ark powders than powders of leaves. Good extraction more than $80.0 \%$ have been observed with all the sorbents derived from stem powders even at $1.0 \mathrm{hr}$ of equilibration (Vide Graph No.A:1b,2b and 3b).

The maximum extractability of Nitrate is $97 \%$ percent at pH: 2 after an equilibration period of 5 hrs for Phyllanthus Neruri leaves powders while with its stem powders, the extractability is found to be found to be enhanced to $100 \%$ at pH:2 after an equilibration period of 5 hrs (vide Graph No.A:1a \&b). With leaves powders of Moringa Tinctoria, 86\% of extraction of for Nitrate is found at pH:2 at an equilibration period of $6 \mathrm{hrs}$ while with its bark powders, $94 \%$ of extraction is found at $\mathrm{pH}: 2$ and equilibration period of $5 \mathrm{hrs}$ is found to be adequate (vide Graph No. A: $2 \mathrm{~b} \mathrm{\& b}$ ). Azadiracta Indica leaves powders are found to remove 99\% Nitrate at pH: 2 after an equilibration period of 5 hrs while with its bark powders, the \% of removal is found to be $100 \%$ at pH: 2 at equilibration period of 5hrs (vide Graph No.:3a\&b).

4. When percentage removal is studied with respect to adsorbent dosage at fixed optimum $\mathrm{pH}$ : 2 and at optimum equilibration times, the graphs increase up to certain dosage and from then onwards plateaus are obtained (vide Graph Nos. C:1 \& 2). 

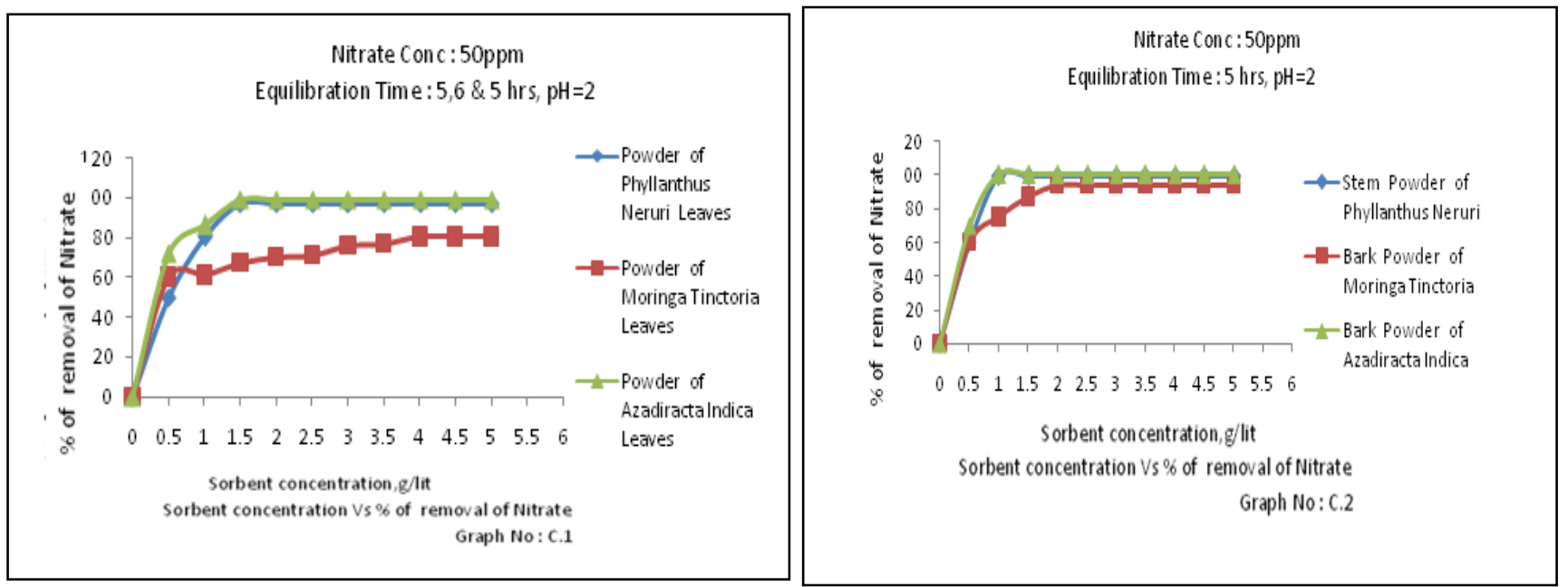

With powders of leaves, the optimum sorbent dosage is found to be $1.5 \mathrm{~g} /$ lit for Phyllanthus Neruri and Azadiracta Indica and $4 \mathrm{~g} / \mathrm{lit}$ for Moringa Tinctoria(vide Graph Nos::C:1\&2). With the powders of stems/barks, the sorbent concentration needed is considerably low. The sorption concentrations needed at optimum conditions of pH:2 and equilibration time are found to be $1 \mathrm{~g} /$ lit for Phyllanthus Neruri and Azadiracta Indica and $2 \mathrm{~g} /$ lit for Moringa Tinctoria(vide Graph Nos::C:1\&2).

\section{Effect of Interfering ions:}

The extractability of Nitrates in presence of Sulphates is markedly affected. Phosphate, Chlorides, Fluorides and carbonates have marginal effect. Cations envisaged synergetic increase in the percentage of extraction.

\section{DISCUSSIONS}

With the available data, it is not possible to propose sound theoretical grounds for each observation as further probe is needed on the surface morphology. It is beyond the aims of this work. However, the behaviors may be accounted for the $\mathrm{pH}$ sensitive dissociation nature of surface functional groups present in these biomaterials namely $-\mathrm{OH}-/-\mathrm{COOH}$. These groups dissociate at high $\mathrm{pH}$ values imparting negative charge to the surface and thereby a thrust for cations prevails on the surface. But as the $\mathrm{pH}$ decreases, the functional groups get protinated endowing positive charge to the surface which results in thrust for anions at the surface at low pHs. Nitrate being an anion is adsorbed by these materials at low pHs and thus results in higher $\%$ of removal. As pH increases, the deprotination occurs and hence the affinity of the adsorbent towards the Nitrate decreases and thus resulting in low \% removal of Nitrate ions.

The decrease in the rate of adsorption with the progress in the equilibration time may be due to the more availability of adsorption sites initially and are progressively used up with time due to the formation of adsorbate film on the sites of adsorbent and thus resulting in decrease in capability of the adsorbent.

\section{Applications:}

The methodologies developed were applied to the real samples of diverse nature, and the results were presented in the Table No: 2. It can inferred that the procedures developed are remarkably successful.

\section{CONCLUSIONS}

a) Bio-adsorbents derived from leaves, stems or barks of Phyllanthus Neruri, Moringa Tinctoria and Azadiracta Indica have been probed for their sorption abilities towards Nitrate ions.

b) Extraction conditions such as $\mathrm{pH}$, sorbent dosage and time of equilibration have been optimized for the maximum removal of Nitrates.

c) We claim 97\%, 86\% and 99.0\% removal of Nitrate with the powders of leaves of Phyllanthus Neruri , Moringa Tinctoria and Azadiracta Indica respectively from synthetic waters at pH: 2 and at optimum equilibration times and sorbent dosage. 
d) With the stems powders of Phyllanthus Neruri, Moringa Tinctoria and Azadiracta Indica, the \% of removal of Nitrate is found to be $100.0 \%, 94.0 \%$ and $100.0 \%$ respectively at optimum conditions of extraction.

e) Percentage of extraction is more in the case of stem powders than with their respective leaves powders. More than $80.0 \%$ extraction is noted even at equilibration time $1.0 \mathrm{hr}$ with all the stem powders of present study.

f) Sorbent dosage and time of equilibration needed for effective removal of Nitrates is found to be less for stem powder than with the corresponding leaves powders.

g) Fivefold excess of cations like $\mathrm{Ca}^{2+}, \mathrm{Cu}^{2+}, \mathrm{Zn}^{2+}$ and $\mathrm{Mg}^{2+}$ are synergistically increasing the extraction. Sulphates is effecting the $\%$ of extraction markedly while $\mathrm{Cl}^{-}$, carbonates, fluorides and phosphates $\left(\mathrm{H}_{2} \mathrm{PO}_{4}{ }^{-} / \mathrm{H}_{3} \mathrm{PO}_{4}\right.$ ionic forms at $\mathrm{pH}: 2)$ marginally effect the extraction at the optimum conditions cited in the Table: 1.

h) The procedures developed are found to be remarkably successful with some real sample of industrial effluents and polluted lakes.

\section{REFERENCES}

1. $\quad$ S.P. Ponde, M.Z. Hasan and Sexena K L, J.I.W.W.A. XVIII (3),1986, 145.

2. C.E. Boyd and C.S. Tucker C S, Pond Aquaculture Water Quality Management, Kluwer ( Academic Publishers: Boston, 1998).

3. M.G. Poxton M G and S.B. Allhouse S B , Aquacult. Eng. 1, 1982, 153.

4. APHA, Standard Methods for the Examination of Water and Wastewater, 20th ed.,. Edited by Lenore S. Clesceri, Arnold E. Greenberg and Andrew D. Eaton, (American Public Health Association: Washington, DC. 1998)

5. G.R. Halberg and D.R. Keeney, Regional Ground-water Quality, (Van Nostrand Reinhold, New Yor, 1993), 297-322.

6. $\quad$ S. Lin and C. Wu C, Wat. Res. 30,1996, 715.

7. J.Virkutyte and V. Jegatheesan V, Bioresour. Technol. 100, 2009, 2189.

8. J. Virkutyte, E. Rokhina and V. Jegatheesan (2010), Bioresour. Technol. 101, 2010,1440.

9. J. Foley, D. Haas, Z. Yuan and P. Lant, Water Res. 44,2010, 831.

10. M.A. Gómez, J. González-López , H. Hontoria-Garcia, J. Hazar. Mat., , B80, 2000, 69- 80

11. S. Velizarov, J.G. Crespo, M.A., Reis. Biotechnol Prog. 18(2), 2002, 296-302.

12. C. Garbisu , D.O. Hall and J.L. Serra, J. Appl. Phycol. 4, 1992, 139.

13. M. Emamjomeh and M. Sivakumar, J. Environ. Manag.. 90, 2009, 663.

14. D. Reyter ,D. Bélanger and L. Roué L, Water Res. $44,2010,1918$.

15. C.C. Sun and T.C. Chou , J. Mol. Catal. A: Chem. 151, 2000, 133

16. C.C. Sun and T.C. Chou T C, Ind. Eng. Chem. Res. 38, 1999, 4545.

17. N.S. Abuzaid, A. Al-Hamouz Bukhari and M.H. Essa , Water Air Soil Pollut. 109, $1999,429$.

18. D. De , E.E. Kalu ,P.P. Tarjan and J.D. Englehardt, Chem. Eng. Technol. 2 ,2004, 56.

19. Di'az V, Ibanez R, Gomez P, Urtiaga A.M. and Ortiz I, Water Res. 45,2010, 125.

20. Saleem, M, Chakrabarti and M H, Diya"uddeen Basheer Hasan, African J of Biotechnology 10 (73) , 2011, 1656.

21. Korngold E, "Removal of nitrates from potable water by Ion-exchange", Water, Air, Soil pollution, 2,1973, 15-22.

22. D. Cliffor D and W.J. Weber Jr , "Nitrate removal from water supplies", EPA-600/2-78-052, U.S. Envi. Protection Agency (EPA), Cincinnata, Ohio,1978.

23. R.P. Lauch and G.A. Guter G A, "Ion Exchange for the removal of Nitrate from well water", J AWWA, 78(5),1986, 83-88.

24. J.E. Zajic , Water Pollution Disposal and Reuse, Volume 1, (Marcel Dekkr, New York City 1971$) 389$.

25. I. Shuval Hillel I, Water Renovation and Reuse (Academic Press, New York City, 1977), 463.

26. Environment Directorate, Waste Water Treatment Processes for Phosphorous and Nitrogen Removal, Organization for Economic Co-operation and Development, Paris, 109 (1974).

27. A. Guter Gerlad A, "Removal of Nitrate from Contaminated Water Supplies for public Use", Environmental Protection Agency, Cincinnati, 1981.

28. A.F. Miquel, and M. Oldani M "A newly developed process for removal of nitrate from drinking water", Nitrate contamination: exposure, consequences and control, Bogardi I and Kuzelka R D, Eds, SpringerVerlag, Germany, 1991, 385-394 
29. S. Horold , T. Tacke and K.D.Vorlop, "Catalytic removal of Nitrate and Nitrite from drinking water:1: Screening for hydrogenation catalysts and influence of reaction conditions on activity and selectivity", Environ. Technol. 14,1993, 931-939.

30. Katsuya Abe, Atsue Imamaki and Morio Hirano, J. of Applied Phycology 14(2) ,2002, 129.

31. C. Polatides ,M. Dortsiou and G. Kyriacow , Electrochimica Acta 50(25-26), 2005, 5237.

32. Nes, e Öztürk, T and Ennil Köse Desalination 223, 2008, 174.

33. R. Ansari, N. Khoshbakht Fahim and A. Fallah Delavar, The Open Process Chemistry Journal, 2, 2009,1-5.

34. Amir, Hossein Mahvi, Dariush, Naghipur, Forugh, Vaezi, Shahrokh and Nazamara., American Journal of Applied Sciences. 2(1), 2005, 372

35. Y. Orhan, and Buyukgungor, Water Sci. Technol. 28, 1993, 247.

36. R.K. Trivedy, Pollution Management in Industries ( Environmental Publications, $2^{\text {nd }}$ Ed. Karad, India 1995).

37. Gerard Kiely, Environmental Engineering, (McGraw-hall International Editions 1998).

38. $\quad$ M.J. Baker, D.W. Blowes, and C.J. Ptacek, Environ Sci. Technol., 32, 1998, 2308.

39. S.H. Huang and B. Chiswell, Water Science and Technology, 42(2-3) ,2000, 295.

40. T. Vaughan, C.W. Seo and W.E. Marshal, Bioresour. Technol. 78, 2001, 133.

41. M.R. Unnithan, V.P. Vinod, and T.S. Anirudhan , J. Appl. Polym. Sci. 84, 2002, 2541.

42. A. Shukla , Y H Zhang , P. Dubdey, J.L.. Margrave and S.S. Sukla, J. Hazard Materrials 95, 2002, 137.

43. N.V. Majeti and R. Kumar, React. Funct. Polym. 46, 2000, 1.

44. M.A. Tshabalaka, K.G. Karthikeyan and Wang D , J.Appl.Polym. Sci. 93, 2004, 1577.

45. Dinesh Mohan and U. Charles and Pittman Jr, J of Hazardous Materials 137(2) , 2006, 762.

46. N. Boujelben and J. Bouzid J, J. of Hazardous Materials, 151(1) , 2008, 103.

47. Sandhya Babel and Tonni Agustions Kurniawan (2003), J of Hazardous materials 97 , 2003, 219.

48. LuzE. De-Bastan and Yoav Bashan, Water Research, 38 , 2004, 4222 (a review article and other reference in it).

49. Yunus Cengeloglu, Ali Tor, Mustafa Ersoz, Gulsin Arslan Separation and Purification Technology, 51 (3) , 2006, 374-378

50. $\quad$ S.V. Khan, and A. Moheman, Poll.Res., 25(1) , 2006, 99.

51. Meera, D and Charan, Poll. Res. 25(1), 2006, 97.

52. M. Divya Jyothi, K. Rohini Kiran and K. Ravindhranth, IJABPT. 2(4),2011, 330-51.

53. M. Divya Jyothi , K. Rohini Kiran and K. Ravindhranth, ESAIJ, 7(2), 2012, : 47-56.

54. Y. Hanumantha Rao, M. Kishore and K. Ravindhranath ,. IJABPT. 2(4), 2011, 323-29.

55. Y. Hanumantha Rao , M. Kishore and K. Ravindhranath, International J of Plant, Animal and Environmental Science, 1(3), 2011.

56. M. Suneetha and K. Ravindhranath, Der Pharma Chemica, 4 (1), 2012, 214-227

57. Metcalf and Eddy, Wastewater Engineering: Treatment of Reuse. 4th. Ed McGraw Hill Co., New York, 2003).

58. Vogel, Arthur I. "A Text Book of Quantitative Inorganic Analysis including Elementary Instrument Analysis", ( $3^{\text {rd }}$ Ed., ELBS, (1961). 
Table No. :1: Effect of interfering Ions on the Extractability of NITRATE with different Bio-sorbents:

\begin{tabular}{|c|c|c|c|c|c|c|c|c|c|c|c|}
\hline \multirow{2}{*}{ S.No } & \multirow[b]{2}{*}{$\begin{array}{l}\text { Adsorbent } \\
\text { and its } \\
\text { concentrati } \\
\text { on }\end{array}$} & \multirow{2}{*}{$\begin{array}{l}\text { Maximum } \\
\text { Extractability at } \\
\text { optimum } \\
\text { conditions }\end{array}$} & \multicolumn{9}{|c|}{$\begin{array}{l}\text { Percentage Extractability of Nitrate in presence of fivefold excess of }(250 \\
\text { ppm) interfering ions at optimum conditions: Conc of Nitrate: } 50 \mathrm{ppm}\end{array}$} \\
\hline & & & $\mathrm{SO}_{4}{ }^{2-}$ & $\mathrm{PO}_{4}{ }^{3-}$ & $\mathrm{Cl}^{-}$ & $\mathrm{CO}_{3}{ }^{2-}$ & $\mathbf{F}^{-}$ & $\mathrm{Ca}^{2+}$ & $\mathrm{Cu}^{2+}$ & $\mathbf{Z n}^{2+}$ & $\mathbf{M g}^{2+}$ \\
\hline 1 & $\begin{array}{l}\text { Powder of } \\
\text { Phyllanthus } \\
\text { Neruri } \\
\text { leaves }\end{array}$ & $\begin{array}{l}97.0 \% ; \\
\text { pH: 2; } 5.0 \text { hrs; } \\
\text { sorbent dosage: } 1.5 \\
\text { gm/lit }\end{array}$ & 74.5 & 85.5 & 83.5 & 84.5 & 91.5 & 97.5 & 98.5 & 99.5 & 99.0 \\
\hline 2 & $\begin{array}{l}\text { Powder of } \\
\text { stem of } \\
\text { Phyllanthus } \\
\text { Neruri }\end{array}$ & $\begin{array}{lrr}100.0 \% ; & \\
\text { pH:2; } 5.0 \quad \text { hrs; } \\
\text { sorbent } & \text { dosage: } \\
1.0 \mathrm{gm} / \text { lit } & & \end{array}$ & 66.5 & 87.2 & 84.5 & 85.3 & 92.5 & 98.2 & 97.3 & 98.6 & 99.5 \\
\hline 3 & $\begin{array}{l}\text { Powder of } \\
\text { Moringa } \\
\text { Tinctoria } \\
\text { leaves: }\end{array}$ & $\begin{array}{l}86.0 \% ; \\
\text { pH:2, } 6.0 \mathrm{hrs} \\
\text { Sorbent dosage: } 4.0 \\
\text { gms/lit }\end{array}$ & 62.5 & 81 & 79.5 & 86.1 & 92.9 & 86.8 & 87.3 & 89.3 & 90.7 \\
\hline 4 & $\begin{array}{l}\text { Powder of } \\
\text { Moringa } \\
\text { Tinctoria } \\
\text { stems: }\end{array}$ & $\begin{array}{lll}94.0 \% & & \\
\text { pH:2, } \quad 5.0 & \text { hrs; } \\
\text { Sorbent } & \text { dosage: } & 2.0 \\
\text { gms/lit } & & \end{array}$ & 63.5 & 82 & 85.3 & 83.7 & 90.1 & 95.5 & 96.5 & 97.5 & 98.5 \\
\hline 5 & $\begin{array}{l}\text { Powder of } \\
\text { Azadiracta } \\
\text { Indica } \\
\text { leaves }\end{array}$ & $\begin{array}{lc}99.0 \% ; & \mathrm{pH}: 2 ; \quad 5.0 \\
\text { hrs; } & \text { Sorbent } \\
\text { dosage: } 1.5 & \mathrm{gms} / \mathrm{lit}\end{array}$ & 68.5 & 84.4 & 84.5 & 85.2 & 87.8 & 99.5 & 99.0 & 98.5 & 100.0 \\
\hline 6 & $\begin{array}{l}\text { Powder of } \\
\text { stems of } \\
\text { Azadiracta } \\
\text { Indica }\end{array}$ & $\begin{array}{lll}100.0 \% & & \\
\text { pH:2, } \quad 5.0 \quad \text { hrs; } \\
\text { Sorbent } \\
\text { gms/lit }\end{array}$ & 67.5 & 80.4 & 88.4 & 90.8 & 90.5 & 100.0 & 100.0 & 100.0 & 100.0 \\
\hline
\end{tabular}


TABLE NO.2: \% OF EXTRACTABILITY OF NITRATES FROM DIFFERENT POLLUTED WATERS WITH BIO-SORBENTS DEVELOPED IN THIS WORK

\begin{tabular}{|c|c|c|c|c|c|}
\hline \multirow[b]{2}{*}{ Bio-Sorbent } & \multicolumn{5}{|c|}{$\%$ of Extractability of Nitrites } \\
\hline & $\begin{array}{l}\text { Sample 1: } \\
\text { Found to } \\
\text { have } \\
55 \text { ppm of } \\
\text { Nitrate }\end{array}$ & $\begin{array}{l}\text { Sample } 2 \\
\text { Found to } \\
\text { have } \\
65 \text { ppm of } \\
\text { Nitrate }\end{array}$ & $\begin{array}{l}\text { Sample } 3 \\
\text { Found to have } \\
84.5 \text { ppm of } \\
\text { Nitrate }\end{array}$ & $\begin{array}{l}\text { Sample } 4 \\
\text { Found to } \\
\text { have } \\
68.5 \text { ppm } \\
\text { of Nitrate }\end{array}$ & $\begin{array}{l}\text { Sample } 5 \\
\text { Found to } \\
\text { have } \\
102.0 \text { ppm of } \\
\text { Nitrate }\end{array}$ \\
\hline $\begin{array}{l}\text { Leaves powder of Phyllanthus } \\
\text { Neruri } \\
\text { :at pH:2; Equilibration time: } 5 \mathrm{hrs} \\
\text { and sorbent concentration: } 1.5 \\
\text { gms/lit }\end{array}$ & $85.5 \%$ & $88.5 \%$ & $87.5 \%$ & $81.5 \%$ & $80.5 \%$ \\
\hline $\begin{array}{l}\text { Stems powder of Phyllanthus } \\
\text { Neruri : } \\
\text { at pH:2; Equilibration time: } 5 \mathrm{hrs} \\
\text { and sorbent concentration: } 1.5 \\
\text { gms/lit }\end{array}$ & $90.5 \%$ & 88.5 & $86.5 \%$ & $89.5 \%$ & $90.5 \%$ \\
\hline $\begin{array}{l}\text { Leaves powder of Moringa } \\
\text { Tinctoria } \\
\text { :at pH:2; Equilibration time: } 6 \mathrm{hrs} \\
\text { and sorbent concentration: } 4.0 \\
\text { gms/lit }\end{array}$ & $76.5 \%$ & 75.5 & $76.5 \%$ & $84.5 \%$ & $82.4 \%$ \\
\hline $\begin{array}{l}\text { Stems powder of Moringa } \\
\text { Tinctoria } \\
\text { :at pH:2; Equilibration time: } 6 \mathrm{hrs} \\
\text { and sorbent concentration: } 2.0 \\
\text { gm/lit }\end{array}$ & $86.5 \%$ & $87.9 \%$ & $88.5 \%$ & $90.5 \%$ & $88.0 \%$ \\
\hline $\begin{array}{l}\text { Leaves powder of Azadiracta } \\
\text { Indica } \\
\text { :at pH:2; Equilibration time:5 hrs } \\
\text { and sorbent concentration: } 1.5 \\
\text { gms/lit }\end{array}$ & $88.1 \%$ & $86.0 \%$ & $91.2 \%$ & $93.8 \%$ & $91.2 \%$ \\
\hline $\begin{array}{l}\text { Stems powder of } \\
\text { Indica } \text { :at } \mathrm{pH}: 2 \text {; Equilibracta } \\
\text { time: } 5 \mathrm{hrs} \text { and sorbent } \\
\text { concentration: } 1.0 \mathrm{gms} / \mathrm{lit}\end{array}$ & $89.5 \%$ & $90.5 \%$ & $92.0 \%$ & $92.5 \%$ & $96.5 \%$ \\
\hline
\end{tabular}

